\title{
INFLUENCE OF WALNUT ON THE NUTRITIONAL AND PHYSICOCHEMICAL PROPERTIES OF BISCUITS MADE FROM WHOLE WHEAT
}

\author{
*Dauda, A. O., Abiodun, O. A., Akintayo. O. A., Babayeju, A. A., Salami, K. \\ O. and Oyekanmi, I. A.
}

Department of Home Economics and Food science, University of llorin, Ilorin, Kwara State.

*Corresponding Author: adegboladauda@yahoo.com; dauda.ao@unilorin.edu.ng

\begin{abstract}
In this study, the influence of walnut flour in biscuit production was studied. Biscuits were made from blends of whole wheat with walnut flours and were assessed for quality attributes and storability. Walnut was blended with wholewheat thus: B (2\%:98\%); C (4\%:96\%); D (6\%:94\%); E (8\%:92\%) and F (10\%:90\%), while plain whole wheat flour served as control (Sample A). The biscuits were baked in the oven operated at $180^{\circ} \mathrm{C}$ for $20-30$ minutes, cooled, packaged, stored for eight weeks, and analysed for physicochemical, microbial and sensory properties using standard methods. The results revealed that the proximate composition of the samples during storage were as follows: protein, moisture, ash, crude-fat, crude-fibre and carbohydrate values ranged thus: (9.30-14.26\%), (10.28-12.06\%), (2.20-2.92\%), (13.24$16.66 \%),(0.69-1.17 \%)$ and $(53.60-61.47 \%)$ respectively, with better nutrient stability in the treated samples when compared to the control. The colour varied with increasing substitution, while the essential amino acids were higher in the walnut-supplemented samples. The microbial load of the control was higher than those of the treated samples, due to high antioxidant activity of walnut. Sensory evaluation revealed that biscuit sample having $2 \%$ walnut flour was most preferred.
\end{abstract}

Keywords: Whole wheat flour; walnut; proximate composition; antioxidant properties; shelf life. 


\section{INTRODUCTION}

Biscuits are snacks made from unpalatable baked dough transformed into an appetizing product (Onabanjo and Ighere, 2014), and usually enjoyed by all age groups. They are rich in fat and carbohydrate, as well as protein and minerals, and as a result, supply energy.

Bakery products, mostly made from wheat flour, are fast foods loved by every age-group for their ease of transportation, taste, cholesterol-free, containing digestive and dietary principles of vital importance, low cost and more convenient with longer shelf-life (Farheena et al., 2015; Ajibola et al.; 2015). Wheat flour has been partially substituted with flour from other plant materials such as from soybean (Mathew-Njoku, 2005). It should however be noted that cereals generally are good raw materials for pastry and other snack products (Abayomi et al., 2006), as good food improves the nutritional status of both man and animal (Okukpe et al., 2011). The wheat is processed into flour used for various pastry products, as it is very rich in protein, carbohydrates, minerals, B-group vitamins and dietary fibre. However, refining it leads to mineral and dietary fibre losses, which may cause diseases such as large bowel cancer, coronary artery disease, and diabetes, thus calling for more consumption of unrefined grains, though refined flour is used mostly in the production of many confectionaries and baked goods (Florence-Suma et al., 2014). Records have it that wheat and wheat-based composite flour have been used to produce high nutritional and sensory products such as cookies, biscuits etc. (Okpala and Okoli, 2011; Emenike et al., 2015).

Walnuts are edible seeds cultivated for their delicacy, and consumed as snacks for refreshments, especially in Nigeria. Walnut, known as Tetracarpidium conophorum or Plukenetia conophora, according to Oyekale et al. (2015) and Edem et al. (2009), and of Euphorbiaceae family, is known as "awusa" or "asala" by the Yorubas, "ukpa" or "oke okpokirinya" by the lgbos and "gawudi bair" by Hausas (Chijoke et al., 2015; Kanu et al., 2015), as well as being a good source of vitamins and minerals. Malnutrition is one of the nutritional problems of mostly the Third World, contributing to infant mortality, poor physical and intellectual development, and low resistance to diseases. Most times, it is caused not by lack of sufficient food, but lack of essential nutrients (Merriam Webster, 2013), though should be noted that nutrient improvement is not the sole thing (Pasqualone et al., 2013). Since wheat is poor in some essential amino acids and micro nutrients; fortifying with walnut, which is rich in micronutrients and the essential amino acids possibly lacking in the wheat flour, could help improve nutrition and equally reduce cost of wheat importation. This study then investigates the physicochemical, amino acid profile, as well as the sensory properties of the biscuit to be produced. 


\section{MATERIALS AND METHODS}

Freshly sourced walnut was processed into flour using modified method of Lucretia et al. (2016). The walnut was sorted, washed, boiled, de-shelled, sliced thinly and dried in the oven at $70^{\circ} \mathrm{C}$ for 7 hours before milling into flour. The walnut flour was blended with wheat flour in the ratio $2 \%$ to $10 \%$. The flour was blended with other required ingredients to produce biscuit using the modified method of Dauda et al. (2018). The flour with the other ingredients was kneaded properly, cut into the desired shapes and baked in the oven at $180^{\circ} \mathrm{C}$ for 30 minutes. The baked biscuits were cooled and packaged for analysis.

The bulk density and water holding capacity of flour samples were determined by Onabanjo and Ighere (2014) method, while the method of Onwuka (2005) was used for oil absorption capacities.

Proximate compositions of the samples were evaluated using standard methods of the Association of Official Analytical Chemist (AOAC, 2012) at week zero and after eight weeks of storage.

Amino acid profile was determined at zero and eight weeks using the method of Benitez, 1989. Soxhlet extraction method (AOAC, 2012) was used to defat. Tryptophan was done separately since $6 \mathrm{~N} \mathrm{HCl}$ destroy it during hydrolysis. Sample colour was done at zero and eight weeks using Oyeyinka et al. (2014) method. CIE tristimulus $L$, $a$ and $b$ parameters were measured with a Chroma meter.

Antioxidant activity was measured with DPPH assay method of Lee and Petersen (2003). For stock reagent solution $\left(1 \times 10^{-3} \mathrm{M}\right), 22 \mathrm{mg}$ of DPPH was dissolved in $15 \mathrm{ml}$ of methanol (stored at $-18^{\circ} \mathrm{C}$ to $-20^{\circ} \mathrm{C}$ ). Working solution had $6 \mathrm{ml}$ of stock solution mixed with $100 \mathrm{ml}$ of methanol to obtain absorbance value of $0.8 \pm 0.02$ at $515 \mathrm{~nm}$ on a spectrophotometer. $0.1 \mathrm{ml}(\mathrm{w} / \mathrm{v})$ of each sample was vortexed for 30 seconds with $3.9 \mathrm{ml}$ of DPPH solution, left for 30 minutes, and absorbance read at $515 \mathrm{~nm}$, while plain DPPH solution served as the control.

Microbial loads were determined over eight weeks, to assess the level of preservation.

Sensory evaluation covered taste, appearance, aroma, and overall acceptability, and rated on a 9-point Hedonic Scale of 1 (disliked extremely) to 9 (liked extremely), using fifty regular consumers of biscuits. Data collected were subjected to statistical analyses using SPSS 15 . The scores were ranked and analyzed using ANOVA with probability level of $p>0.50$ and differences separated with Duncan` multiple test range (Duncan, 2001). 


\section{RESULTS AND DISCUSSION}

Functional property (Table 1) determines the usefulness of flours (Adebowale et al. 2012). Bulk density determines the packaging requirement and handling of food products. The bulk density of whole wheat flour (WWF) was $1.49 \mathrm{~g} / \mathrm{ml}$, while African walnut flour (AWF) was $0.35 \mathrm{~g} / \mathrm{ml}$; implying samples with high quantity of WWF would need extra care in package designs. Swelling capacity is a reflection of associative forces within flour granules. Swelling capacity of WWF was 2.80, and AWF, 127.61. Water absorption is desirable in food systems to improve yield and consistency, give body to foods, and enhance water retention (Osundahunsi et al., 2003). However, the protein content in the flour may affect the water absorption and swelling through reduction in the interaction between protein and starch (Aprianita et al., 2009). Water absorption capacity of AWF was $118.42 \mathrm{ml} / \mathrm{g}$, while that of WWF was $1.80 \mathrm{ml} / \mathrm{g}$. High value of AWF may be attributed to lose structure of its starch polymer, as against WWF compact nature (Ajanaku et al., 2012). Oil absorption capacity, which represents amount of oil flour can pick up per gram, this is important in food industries for flavour retention, shelf life improvement and palatability (Kumar et al., 2011). AWF had oil absorption capacity of $23.74 \mathrm{ml} / \mathrm{g}$, while WWF had $0.86 \mathrm{ml} / \mathrm{g}$. This indicates that incorporating walnut into dough increases the fat content if the added fat is not moderated, though it leads to improved flavour.

Table 2 shows the proximate composition at zero and eight weeks, respectively, with significant differences $(a t p<0.05)$. Moisture content varied between the control and treated samples, increasing during storage. At week zero, it ranged from $4.35 \%$ to $6.76 \%$, but rose to between $10.29 \%$ and $12.06 \%$ after eight weeks. The increment noticed was due to absorption likely through the pinholes of the packaging materials and/or ambient temperature of storage, which definitely influenced shelf life of the products. Crude fat contents were significantly different $(p<0.05)$ from each other. Sample $F$ ( $10 \%$ substitution level) had the highest value of $16.81 \%$, followed by Sample E (8\% substitution level) with $15.98 \%$ at week zero. However, the control, during same period, had the least fat content (13.19\%). Higher values of the treated samples may be due to the reported high oil content of the walnut (Ndie et al., 2010; Ekwe and Ihemeje, 2013). According to Romoke (2009), walnut oil is a good source of protective omega 3 essential fatty acids the body cannot manufacture. As such, the biscuit from the blends would supply consumers with this essential fatty acid. High ash content in foods depicts high mineral contents. The ash content of the samples ranged from $2.19 \%$ to $2.54 \%$, with slight reduction in the $2 \%$ substitution and control after eight weeks. Ash content increased with substitution, implying increased mineral content. Protein content ranged from $9.27 \%$ to $14.28 \%$ at week zero, with 
$0.03 \%$ to $0.10 \%$ increase to $9.30-14.30 \%$ after storage at $27 \pm 2{ }^{\circ} \mathrm{C}$, with significant differences $(\mathrm{p}<0.05)$. Sample $\mathrm{F}$ had the highest crude protein value $(14.28 \%$ and $14.30 \%)$, followed by Sample E (13.99\% and $14.09 \%)$, but the control, $9.27 \%$ to $9.30 \%$. These results are in agreement with that of Ndie et al. (2010) and Ekwe and Ihemeje (2013), who reported high protein for walnut. Crude fibre of the samples ranged from $0.62-1.16 \%$ and $0.69-1.17 \%$ at zero and eight weeks respectively, with significant differences recorded. The fibre content increased with added walnut. Carbohydrate content, which was obtained by difference, ranged from $60.87-69.05 \%$ at week zero, and decreased at storage though the control had the highest value (61.47\%).

The amino acid profile of the samples (Table 3 ) showed that the samples had all the essential amino acids, though in smaller amounts with more in treated samples, implying improved nutrient in the walnut samples. Moisture uptake could have caused slight concentration reduction during storage, and not actual. Increased amino acids could be due to added walnut (rich in protein) (Ndie et al., 2010; Ekwe and Ihemeje, 2013), suggesting improvement in nutrient of the samples.

Table 4 shows the colour and antioxidant composition of the samples. The colour of a product determines its acceptability, as it attracts consumers. Results showed significant differences $(p<0.05)$ among some of the samples. The $L^{*}$ values ranged from 50.12 to 54.07 ; with Sample $C$ having the least value, while Sample $B$, had the highest. Variation/reduction in values may depend on ingredient composition, air velocity within the oven, and red pigmentation due to maillard reaction or non-enzymatic browning. The amount of reducing sugars and amino acids/proteins available, as well as the baking temperature/time reported by Pereira et al. (2013) could also be possible factors. Positive values of $a^{*}$ and $b^{*}$ showed samples redness and yellowness qualities, with $\mathrm{a}^{*}$ ranging from 4.87 to 6.34 , and $\mathrm{b}^{*}, 15.9$ to 17.56 ; Sample $\mathrm{F}$ having highest values due to high walnut proportion. The increment at storage was probably due to changes in internal rheology caused by storage time and/or temperature.

Samples having walnut had higher DPPH radical scavenging activity (Table 4), with results ranging from $23.55 \mu \mathrm{g} / \mathrm{ml}$ to $39.03 \mu \mathrm{g} / \mathrm{ml}$ at week zero and $22.66 \mu \mathrm{g} / \mathrm{ml}-38.52 \mu \mathrm{g} / \mathrm{ml}$ during storage. Sample D had the highest value at zero and eight weeks. Decreased antioxidant activity during storage could be due to the action of spoilage microorganisms aided by moisture uptake. The moisture may have aggravated phenolic polymerization, affecting phenol ex6traction leading to reduced antioxidant activity (Ekwe and Ihemeje 2013; Pokorny and Schmidt, 2.003). As a result, addition of walnut may increase health benefits through antioxidant properties and dietary fibre content, thus corroborating the reports of both Elmastasa et al., 2007 and Halliwell and 
Gutteridge, 2003 that antioxidant-containing foods reduce oxidative damage and deterioration and protect food quality.

A significant increase in bacterial and fungal counts was noticed after eight weeks, most especially for the control (Table 5). Initial microbial counts were not nil for all the samples, likely due to poor handling. At week zero, bacterial count of $2.0 \times 10^{2} \mathrm{CFU} / \mathrm{ml}$ was the highest with no fungal growth, while $2.3 \mathrm{x}$ $10^{4} \mathrm{CFU} / \mathrm{ml}$ and $3.0 \times 10^{3} \mathrm{CFU} / \mathrm{ml}$ respectively were recorded after eight weeks.

The samples with walnut had lowest microbial load, probably due to the activities of antioxidants, which may have reduced microbial invasion. The growth noticed during storage could be due to moisture uptake and ambient temperature of storage, which may hinder good preservation.

Mean values of the samples (Table 6$)$ varied significantly $(p<0.05)$ for appearance, hardness, aroma, taste, and overall acceptability, with appearance and hardness influenced by walnut addition. Aroma scores were not significant, but taste, an important factor for accepting products, varied among the samples. The control sample had the highest mean score for aroma, taste, hardness and overall acceptability (most preferred), but Sample $\mathrm{C}$ was least preferred in terms of aroma and appearance.

\section{CONCLUSION}

This research work revealed that walnut addition has a positive influence on the quality of the biscuit produced. Supplementing WWF with AWF for biscuit production resulted in improved nutritional quality and shelf stability, which was basically achieved by conferring lower moisture content on the biscuit produced, with improved nutritional quality (macro and micro nutrients). It could therefore be concluded that biscuits can be produced from WWF and AWF of up to $10 \%$. Addition of AWF reduces the cost of production with less capital flight, as well as improves its nutrient. 
Table 1: Functional properties of whole wheat and walnut flours.

\begin{tabular}{lllll}
\hline Sample. & $\begin{array}{l}\text { Bulk } \\
\text { Density } \\
(\mathrm{g} / \mathrm{ml})\end{array}$ & $\begin{array}{l}\text { Swelling } \\
\text { Capacity }\end{array}$ & $\begin{array}{l}\text { Water } \\
\text { Absorption } \\
\text { Capacity } \\
(\mathrm{ml} / \mathrm{g})\end{array}$ & $\begin{array}{l}\text { Oil } \\
\text { Absorption } \\
\text { Capacity } \\
(\mathrm{ml} / \mathrm{g})\end{array}$ \\
\hline Walnut Flour & $1.49 \mathrm{a} \pm 0.01$ & $127.61 \mathrm{a} \pm 0.28$ & $118.42 \mathrm{a} \pm 0.12$ & $23.74 \mathrm{a} \pm 0.05$ \\
$\begin{array}{l}\text { Whole Wheat } \\
\text { Flour }\end{array}$ & $0.35 \mathrm{~b} \pm 0.07$ & $2.80 \mathrm{~b} \pm 0.28$ & $1.80 \mathrm{~b} \pm 0.04$ & $0.86 \mathrm{~b} \pm 0.01$ \\
\hline
\end{tabular}

Table 2: Proximate analysis of biscuit samples (week zero) (\%)

\begin{tabular}{|c|c|c|c|c|c|c|}
\hline Sample & Moisture & Crude fat & Ash & $\mathrm{Cp}$ & $\mathrm{Cf}$ & Carbohydrate \\
\hline \multicolumn{7}{|l|}{$\begin{array}{l}\text { Week } \\
\text { zero }\end{array}$} \\
\hline A & $6.75^{a} \pm 0.02$ & $13.19^{\mathrm{e}} \pm 0.03$ & $2.30^{\mathrm{d}} \pm 0.00$ & $9.27^{\dagger} \pm 0.04$ & $0.62^{b} \pm 0.02$ & $69.05^{a} \pm 0.01$ \\
\hline B & $5.22^{\mathrm{c}} \pm 0.03$ & $14.62^{\mathrm{c}} \pm 0.02$ & $2.19^{d} \pm 0.03$ & $11.84^{\mathrm{e}} \pm 0.04$ & $0.87^{f} \pm 0.04$ & $65.27^{\complement} \pm 0.03$ \\
\hline C & $4.37^{d} \pm 0.01$ & $13.50^{d} \pm 0.03$ & $2.45^{b} \pm 0.04$ & $12.29^{d} \pm 0.11$ & $1.05^{\mathrm{e}} \pm 0.04$ & $66.36^{b} \pm 0.19$ \\
\hline D & $5.76^{b} \pm 0.04$ & $15.81^{\mathrm{b}} \pm 0.28$ & $2.34^{c} \pm 0.04$ & $12.67^{\circ} \pm 0.57$ & $0.96^{e} \pm 0.04$ & $62.42^{d} \pm 0.13$ \\
\hline$E$ & $6.05^{\mathrm{a}} \pm 0.04$ & $15.98^{b} \pm 0.04$ & $2.51^{\mathrm{ab}} \pm 0.03$ & $13.99^{b} \pm 0.04$ & $1.12^{b} \pm 0.02$ & $60.37^{\dagger} \pm 0.00$ \\
\hline $\mathrm{F}$ & $4.35^{d} \pm 0.00$ & $16.81^{\mathrm{a}} \pm 0.02$ & $2.54^{\mathrm{a}} \pm 0.03$ & $14.28^{\mathrm{a}} \pm 0.02$ & $1.16^{\mathrm{d}} \pm 0.01$ & $60.87^{e} \pm 0.00$ \\
\hline \multicolumn{7}{|l|}{$\begin{array}{l}\text { Week } \\
\text { eight }\end{array}$} \\
\hline . A & $12.06^{a} \pm 0.04$ & $13.24^{\mathrm{d}} \pm 0.03$ & $2.25^{\mathrm{a}} \pm 0.03$ & $9.30^{f} \pm 0.03$ & $0.69^{d} \pm 0.02$ & $61.47^{a} \pm 0.04$ \\
\hline $6 \mathrm{~B}$ & $10.29^{d} \pm 0.01$ & $14.65^{\mathrm{c}} \pm 0.01$ & $2.20^{\mathrm{a}} \pm 0.01$ & $11.86^{\mathrm{e}} \pm 0.01$ & $0.88^{c} \pm 0.04$ & $60.43^{b} \pm 0.04$ \\
\hline C & $.10 .28^{\mathrm{d}} \pm 0.01$ & $13.46^{\mathrm{d}} \pm 0.06$ & $2.40^{\mathrm{a}} \pm 0.04$ & $12.33^{\mathrm{d}} \pm 0.00$ & $1.00^{\mathrm{b}} \pm 0.04$ & $60.51^{b} \pm 0.14$ \\
\hline D & $10.49^{c} \pm 0.02$ & $15.50^{\mathrm{b}} \pm 0.02$ & $2.36^{a} \pm 0.04$ & $12.67^{\mathrm{c}} \pm 0.04$ & $1.00^{b} \pm 0.04$ & $57.93^{c} \pm 0.04$ \\
\hline$E$ & $11.07^{b} \pm 0.01$ & $15.64^{b} \pm 0.02$ & $2.92^{\mathrm{a}} \pm 0.71$ & $14.09^{b} \pm 0.02$ & $1.11^{\mathrm{a}} \pm 0.02$ & $55.18^{d} \pm 0.69$ \\
\hline $\mathrm{F}$ & $11.61^{\mathrm{b}} \pm 0.04$ & $16.66^{\mathrm{a}} \pm 0.05$ & $2.64^{\mathrm{a}} \pm 0.05$ & $14.26^{\mathrm{a}} \pm 0.02$ & $1.17^{\mathrm{a}} \pm 0.02$ & $53.60^{e} \pm 0.08$ \\
\hline
\end{tabular}

Values are means of duplicate readings (mean \pm standard deviation). Within each column, values with different subscript differ significantly $(<0.05)$.

Key: CP- Crude Protein CF- Crude Fibre

Legend: A-100\% Whole Wheat Flour; B- 98\% Whole Wheat flour, 2\% African walnut flour

C.-96\% Whole Wheat flour, 4\% African walnut flour; D- 94\% Whole Wheat flour, $6 \%$ African walnut flour; E- $92 \%$ Whole Wheat flour, $8 \%$ African walnut flour; $\mathrm{F}$ -

$69.0 \%$ Whol..e Wheat flour, 10\% African walnut flour 
Table 3: Amino acid profile of biscuit samples ( $\mathrm{g} / 100 \mathrm{~g})$

\begin{tabular}{|c|c|c|c|c|c|c|c|c|c|}
\hline Sample & Leucine & Lysine & $\begin{array}{l}\text { Iso- } \\
\text { Leucine }\end{array}$ & $\begin{array}{l}\text { Phenyl- } \\
\text { Alanine }\end{array}$ & $\begin{array}{l}\text { Trypto- } \\
\text { Phan }\end{array}$ & Valine & Methionine & Histidine & Threonine \\
\hline \multicolumn{10}{|l|}{$\begin{array}{l}\text { Week } \\
\text { zero }\end{array}$} \\
\hline$A$ & $5.65^{\dagger} \pm 0.01$ & $2.22^{\mathrm{d}} \pm 0.01$ & $3.02^{\mathrm{cd}} \pm 0.01$ & $4.42^{\mathrm{d}} \pm 0.02$ & $1.15^{\mathrm{e}} \pm 0.01$ & $3.28^{d} \pm 0.03$ & $1.06^{d} \pm 0.02$ & $2.40^{\mathrm{a}} \pm 0.01$ & \\
\hline B & $6.82^{\mathrm{e}} \pm 0.02$ & $3.17^{c} \pm 0.01$ & $2.97^{d} \pm 0.04$ & $4.42^{d} \pm 0.02$ & $1.44^{\mathrm{d}} \pm 0.02$ & $4.05^{b c} \pm 0.07$ & $0.92^{c} \pm 0.01$ & $2.37^{a} \pm 0.01$ & $\begin{array}{l}3.01^{e} \pm 0.03 \\
3.07^{d} \pm 0.04\end{array}$ \\
\hline C & $6.97^{d} \pm 0.04$ & $3.10^{\mathrm{cd}} \pm 0.14$ & $3.30^{a b} \pm 0.14$ & $4.42^{d} \pm 0.02$ & $1.48^{\mathrm{cd}} \pm 0.02$ & $4.00^{c} \pm 0.02$ & $0.94^{\mathrm{c}} \pm 0.01$ & $2.32^{\mathrm{a}} \pm 0.02$ & \\
\hline $\mathrm{D}$ & $7.05^{c} \pm 0.01$ & $3.25^{b c} \pm 0.03$ & $3.19^{b c} \pm 0.01$ & $4.52^{\mathrm{c}} \pm 0.01$ & $1.50^{c} \pm 0.03$ & $4.09^{b} \pm 0.01$ & $0.97^{c} \pm 0.03$ & $2.35^{\mathrm{a}} \pm 0.04$ & $13^{\mathrm{c}} \pm 0.01$ \\
\hline$E$ & $7.13^{b} \pm 0.01$ & $3.34^{b} \pm 0.01$ & $3.26^{b} \pm 0.03$ & $4.61^{b} \pm 0.01$ & $1.57^{b} \pm 0.03$ & $4.23^{a} \pm 0.01$ & $1.13^{b} \pm 0.04$ & $2.40^{\mathrm{a}} \pm 0.01$ & $3.25^{b} \pm 0.03$ \\
\hline$F$ & $7.30^{\mathrm{a}} \pm 0.01$ & $3.53^{a} \pm 0.01$ & $3.45^{\mathrm{a}} \pm 0.07$ & $4.71^{\mathrm{a}} \pm 0.12$ & $1.69^{a} \pm 0.01$ & $4.30^{a} \pm 0.01$ & $1.24^{\mathrm{a}} \pm 0.01$ & $2.43^{\mathrm{a}} \pm 0.02$ & $3.39^{a} \pm 0.01$ \\
\hline \multicolumn{10}{|l|}{$\begin{array}{l}\text { Week } \\
\text { eight }\end{array}$} \\
\hline$A$ & $6.14^{\mathrm{c}} \pm 0.01$ & $2.91^{e} \pm 0.01$ & $2.92^{d} \pm 0.01$ & $4.51^{a} \pm 0.01$ & $1.28^{\mathrm{d}} \pm 0.01$ & $4.02^{\mathrm{a}} \pm 0.02$ & $0.72^{\mathrm{c}} \pm 0.02$ & $2.14^{\mathrm{d}} \pm 0.01$ & $3.01^{f} \pm 0.01$ \\
\hline B & $6.89^{b} \pm 0.01$ & $3.56^{b} \pm 0.01$ & $3.21^{a} \pm 0.01$ & $4.16^{b} \pm 0.01$ & $1.46^{c} \pm 0.01$ & $3.91^{b} \pm 0.01$ & $1.10^{\mathrm{ab}} \pm 0.14$ & $2.42^{\mathrm{a}} \pm 0.01$ & $3.17^{e} \pm 0.01$ \\
\hline C & $6.92^{b} \pm 0.01$ & $3.36^{d} \pm 0.01$ & $3.14^{b} \pm 0.02$ & $4.01^{c} \pm 0.01$ & $1.48^{\mathrm{b}} \pm 0.00$ & $3.80^{\circ} \pm 0.01$ & $0.97^{b} \pm 0.01$ & $2.40^{\mathrm{a}} \pm 0.01$ & $3.30^{d} \pm 0.14$ \\
\hline D & $6.94^{b} \pm 0.01$ & $3.43^{c} \pm 0.01$ & $3.10^{b c} \pm 0.01$ & $3.65^{d} \pm 0.03$ & $1.49^{b} \pm 0.01$ & $3.86^{b} \pm 0.01$ & $0.99^{b} \pm 0.01$ & $2.35^{\mathrm{b}} \pm 0.01$ & $3.63^{c} \pm 0.04$ \\
\hline$E$ & $6.99^{\mathrm{ab}} \pm 0.01$ & $3.53^{b} \pm 0.01$ & $3.07^{b c} \pm 0.00$ & $3.50^{\mathrm{e}} \pm 0.01$ & $1.51^{\mathrm{ab}} \pm 0.01$ & $3.89^{b} \pm 0.01$ & $1.11^{\mathrm{ab}} \pm 0.01$ & $2.34^{\mathrm{c}} \pm 0.01$ & $3.87^{b} \pm 0.07$ \\
\hline$F$ & $7.11^{\mathrm{a}} \pm 0.13$ & $3.66^{a} \pm 0.04$ & $3.01^{c} \pm 0.00$ & $3.46^{f} \pm 0.03$ & $1.54^{\mathrm{a}} \pm 0.02$ & $4.06^{a} \pm 0.06$ & $1.18^{\mathrm{a}} \pm 0.04$ & $2.37^{b} \pm 0.05$ & $4.05^{\mathrm{a}} \pm 0.07$ \\
\hline
\end{tabular}

Values are means of duplicate readings (mean \pm standard deviation). Within each column, values with different subscript differ significantly $(<0.05)$. ${ }^{*}$ Legend as in Table 2. 
Table 4: Colour and antioxidant composition of the biscuit samples.

\begin{tabular}{|c|c|c|c|c|}
\hline $\begin{array}{l}\text { Sample } \\
\text { Week } \\
\text { zero }\end{array}$ & $\mathrm{L}$ & $A$ & $B$ & $\begin{array}{l}\text { Antioxidant } \\
(\mu \mathrm{g} / \mathrm{ml})\end{array}$ \\
\hline$A$ & & & & $23.55^{e} \pm 0.04$ \\
\hline & $51.9^{b} \pm 1.75$ & $6.19^{a b} \pm 1.11$ & $16.39^{b} \pm 0.59$ & \\
\hline B & & & & $31.95^{d} \pm 0.09$ \\
\hline C & $54.0 / a \pm 1.22$ & $4.87^{c} \pm 0.51$ & $16.06^{\mathrm{C}} \pm 0.68$ & $38.71^{a} \pm 0.49$ \\
\hline$D$ & $50.12^{c} \pm 1.99$ & $6.17^{a b} \pm 0.73$ & $15.90^{c} \pm 0.52$ & $39.03^{a}+0.04$ \\
\hline$E$ & $53.18^{a} \pm 0.60$ & $5.43^{b} \pm 0.30$ & $6.90^{a b} \pm 0.35$ & $34.90^{c}+0.18$ \\
\hline $\mathrm{F}$ & $53.98^{a} \pm 0.68$ & $5.10^{c} \pm 0.35$ & $6.51^{b} \pm 0.21$ & $3737^{b}+013$ \\
\hline & $53.08^{a} \pm 0.90$ & $6.34^{a} \pm 0.46$ & $17.56^{\mathrm{a}} \pm 0.17$ & \\
\hline \multicolumn{5}{|l|}{$\begin{array}{l}\text { Week } \\
\text { eight }\end{array}$} \\
\hline$A$ & $56.78^{b} \pm 2.82$ & $6.10^{a} \pm 0.82$ & $13.39^{b} \pm 0.90$ & $22.66^{\mathrm{e}} \pm 0.08$ \\
\hline & $58.50^{\mathrm{a}} \pm 1.47$ & $5.10^{\mathrm{b}} \pm 0.13$ & $12.92^{c} \pm 0.39$ & $31.78^{d} \pm 0.13$ \\
\hline & $54.33^{c} \pm 2.41$ & $6.43^{a} \pm 0.64$ & $12.60^{\mathrm{c}} \pm 1.62$ & $38.32^{a} \pm 0.12$ \\
\hline & $57.80^{a} \pm 1.65$ & $5.66^{a b} \pm 0.36$ & $13.62^{\mathrm{b}} \pm 1.15$ & $38.52^{a} \pm 0.02$ \\
\hline & $56.97^{b} \pm 1.65$ & $6.35^{a} \pm 0.92$ & $14.02^{\mathrm{ab}} \pm 0.64$ & $32.69^{c} \pm 0.04$ \\
\hline & $57.80^{a} \pm 1.65$ & $6.34^{a} \pm 0.58$ & $14.40^{\mathrm{a}} \pm 0.62$ & $35.19^{b} \pm 0.12$ \\
\hline
\end{tabular}

Values are means of duplicate readings (mean \pm standard deviation). Within each column, values with different subscript differ significantly $(<0.05)$.

Key: L-Whiteness; $\quad$ a-Redness; $\quad b$-yellowness; *Legend as in Table 2 
Table 5: Microbial load of biscuit samples

\begin{tabular}{ccc}
\hline Samp6le & $\begin{array}{c}\text { Bacterial } \\
\text { Load(NA } \\
\left(\mathrm{cfu} / \mathrm{ml}^{3}\right)\end{array}$ & $\begin{array}{c}\text { Fungi } \\
\text { Load }\left(\mathrm{PDA}^{3}\right) \\
(\mathrm{cfu} / \mathrm{ml})\end{array}$ \\
\hline Week zero & & \\
\hline A & $2.0 \times 10^{2}$ & $\mathrm{NIL}$ \\
B & $\mathrm{NIL}$ & $\mathrm{NIL}$ \\
C & $1.0 \times 10^{2}$ & $\mathrm{NIL}$ \\
D & $1.0 \times 10^{2}$ & $\mathrm{NIL}$ \\
E & $\mathrm{NIL}$ & $\mathrm{NIL}$ \\
F & $\mathrm{NIL}$ & $\mathrm{NIL}$ \\
\hline Week eight & & \\
\hline A & $2.3 \times 10^{4}$ & $3.0 \times 10^{3}$ \\
B & $2.0 \times 10^{3}$ & $1.0 \times 10^{2}$ \\
C & $2.0 \times 10^{3}$ & $1.0 \times 10^{2}$ \\
D & $2.4 \times 10^{3}$ & $\mathrm{NIL}$ \\
& $1.1 \times 10^{3}$ & $\mathrm{NIL}$ \\
E & $1.3 \times 10^{3}$ & $\mathrm{NIL}$ \\
\hline
\end{tabular}

Legend as in Table 2

Table 6: Mean sensory scores of biscuit samples

\begin{tabular}{clllll}
\hline Sample & Aroma & Appearance & Taste & Hardness & $\begin{array}{c}\text { overall } \\
\text { Acceptability }\end{array}$ \\
\hline A & $6.98^{\mathrm{a}} \pm 1.44$ & $6.68^{\mathrm{ab}} \pm 1.36$ & $7.39^{\mathrm{a}} \pm 0.96$ & $7.30^{\mathrm{a}} \pm 1.11$ & $7.46^{\mathrm{a}} \pm 1.20$ \\
B & $6.58^{\mathrm{a}} \pm 1.53$ & $7.10^{\mathrm{a}} \pm 1.17$ & $6.44^{\mathrm{b}} \pm 1.94$ & $6.58^{\mathrm{b}} \pm 1,70$ & $6.74^{\mathrm{b}} \pm 1.58$ \\
C & $6.36^{\mathrm{a}} \pm 1^{\prime} 64$ & $6.20^{\mathrm{b}} \pm 1.20$ & $6.72^{\mathrm{b}} \pm 1.44$ & $6.74^{\mathrm{ab}} \pm 1.72$ & $6.84^{\mathrm{b}} \pm 1.32$ \\
D & $6.55^{\mathrm{a}} \pm 1.47$ & $7.02^{\mathrm{a}} \pm 1.24$ & $6.16^{\mathrm{b}} \pm 1.58$ & $6.69^{\mathrm{ab}} \pm 1.45$ & $6.88^{\mathrm{b}} \pm 1.29$ \\
E & $6.48^{\mathrm{a}} \pm 1.68$ & $6.68^{\mathrm{ab}} \pm 1.33$ & $6.50^{\mathrm{b}} \pm 1.69$ & $6.78^{\mathrm{ab} \pm 1.20}$ & $6.64^{\mathrm{b}} \pm 1.54$ \\
F & $6.81^{\mathrm{a} \pm 1.53}$ & $6.94^{\mathrm{a}} \pm 1.25$ & $6.04^{\mathrm{b}} \pm 1.79$ & $6.35^{\mathrm{b}} \pm 0.33$ & $6.41^{\mathrm{b}} \pm 1.74$
\end{tabular}

* Legend as for Table 2 


\section{REFERENCES}

Abayomi, Y.A., Arijenja-George, A. and Kolawole, I.A. (2006). Comparative leaf growth and grain yield response of hybrid and open pollinated maize genotype to nitrogen fertilizer application. Agrosearch, 8(1), 13-25.

Adebowale, A.A., Adegoke, M.T., Sanni, S.A., Adegunwa, M.O. and Fetuga, G.O. (2012). Functional properties and biscuit making properties of sorghum-wheat flour composite. American Journal of Food Technology, 7(6), 372 -379.

Ajanaku, K.O., Ajanaku, C., Edobor, O., and Nwinyi, O.C. (2012). Nutritive value of sorghum fortified with groundnut seed. Journal of Food Technology, 7(2), $82-88$.

Ajibola, F.C, Oyerinde O.V. and Adeniyan S.O. (2015). Physicochemical and antioxidant properties of whole wheat biscuits incorporated with Moringa oleifera leaves and cocoa powder. Journal of Scientific Research and Report, 7 (3), 195 - 206.

Association of Official Analytical Chemists (AOAC), (2012). Official Methods of Analysis. Association of Official Analytical Chemists. Washington; D.C. USA.

Aprianita, A., Purwandari, U., Watson, B., and Vasiljevic, T.L. (2009). Physicochemical properties of flours and starches from selected commercial tubers available in Australia. International Food Research Journal, 16, 507-520.

Benitez, L.V. (1989). Amino acid and Fatty acid profiles in aquaculture nutrition studies. In S.S. De-Silva (Ed.) Fish nutrition Research in Asia, Proceedings of the Third Asian Fish Nutrition Network Meeting. Pp. 23-25

Chijoke, O.C., Anosike, C.A. and Ani, C.C., (2015). Studies on the phytochemical and nutritional properties of Tetracarpidium conophorum (black walnut) seeds. Journal of Global Bioscience, 4(2), 1366-1372.

Dauda, A.O., Abiodun, O.A., Oyeyinka, S.A. and Arise, A.K., (2018). Nutritional and consumers' acceptance of biscuit made from wheat flour fortified with partially defatted groundnut paste. LWT - Food Science and Technology, 90, 265-269.

Duncan, M. (2001). Biscuit, cracker and cookies recipes for the food industry. Cornwall England: Woodhead publishing. 
Edem, C.A., Dosunmu, I.M. and Bassey F.I. (2009). Determination of proximate composition, ascorbic acid and heavy metal content of African walnut (Tetracarpidium conophorum). Pakistan Journal of Nutrition, 8(3), 225-228.

Ekwe C.C., Ihemeje A. (2013). Evaluation of physiochemical properties and preservation of African walnut (Tetracarpidium conophorum). Academic Research International, 4 (6), 501 - 512.

Elmastasa, M., Isildaka, O., Turkekulb, I. and Temura, N. (2007). Food Phytochemicals. Journal of Food Composition Analysis, 20, 337-345.

Emenike, N.J.T., Uwe, F.O., Ebere, C.O., and Kin-Kabari, D.B. (2015). Effect of drying methods on the Physicochemical and Sensory Properties of Cookies fortified with Moringa (Moringa oleifera) leaves. Asian Journal of Agriculture and Food Sciences, 3(4), 361 - 367.

Farheena I., Avanish K., and Uzma A. (2015). Development and Quality Evaluation of Cookies Fortified with Date Paste (Phoenix dactylifera L). International Journal of Science and Technology, 3 (4), 2305 - 2314.

Florence-Suma, P., Asna Urooj., Asha, M.R. and lyotona R. (2014). Sensory, Physical and Nutritional Qualities of Cookies prepared from Pearl Millet (Opennisetum Typhoideum), Food Processing and Technology, 5 (10), 377- 385.

Halliwell, B. and Gutteridge, J.M. (2003). What is an Antioxidant? In: Free Radical in Biology and Medicine; Oxford University Press: United Kingdom.

Hidden hunger Merriam Webster (2013). http://www.merriamwebster.com/dictionary/hidden hunger Web 18, July 2013.

Kanu, A.M., Kalu, J.E., Okorie, A.C., Olabinri, B.M., Eniyansoro, O.O., and Okoronkwo, C.O. (2015). Evaluation of chelating ability of aqueous extract of Tetracarpidium conophorum (African walnut) in vitro. International Journal Applied Research in Natural Products, 3 (3), 113.

Kumar, P., Yadav, R.K., Gollen, B., Kumar, S., Verma, R.K and Yadav, S. (2011). Nutritional Contents and the Medicinal Properties of Wheat: A review. Life Sciences and Medicine Research, 22, 1-10.

Lee, C.E. and Petersen C.H., (2003). Effects of developmental acclimation on adult salinity tolerance in the freshwater-invading copepod Eurytemora 
affinis. Physiological and Biochemical Zoology Journal, 76(3), 296301.

Lucretia I. B. and Patience C.O. (2016). Nutrient composition, physical and sensory properties of Wheat-African walnut cookies. Sky Journal of Food Science, 5(4), 24 - 30.

Mathew-Njoku, E.C. (2005). Adoption of Soybean productions in Owerri North Local Government Area of Imo State, Nigeria. Agrosearch, 7 (1\&2), 22 27.

Ndie E.C., Nnamani C.V., Oselebe H.O. (2010). Some physicochemical characteristics of defatted flours derive from African walnut (Tetracarpidium conoforum): an underutilized legume. Pakistan Journal of Nutrition, 9 (9), $909-911$.

Okpala, E.C., and Okoli, E.C. (2011). Nutritional evaluation of cookies produced from pigeon pea, cocoyam and sorghum flour blends. African Journal of Biotechnology, 10 (3), 433 - 438.

Okukpe, K.M., Adeloye, A.A., Badmos, A.H.A., Adeyemi, K.D. and Olaniran, T.O. (2011). Performance of West African Dwarf (WAD) Goats Fed Tridax and Slam Weed in Ficus Based Diets. Agrosearch, 11(1): 69- 76.

Onabanjo, O.O., and Ighere, D.A., (2014). Nutritional, functional and sensory properties of biscuit produced from wheat-sweet potato composite. Journal of Food Technology Research, 1 (2), 111-121.

Onwuka, G.I. (2005). Food analysis and instrumentation; Theory and practice, Lagos, Nigeria: Naphtali prints.

Osundahunsi, O.F., Fagbemi, T.N., Kesselman, E. and Shimoni, E. (2003). Comparison of the physicochemical Properties and Pasting characteristics of Flour and Starch from Red and White Sweet potato cultivars. Journal of Agricultural and Food Chemistry, 51(8), 22322236.

Oyekale, K.O., Odutayo, O.I., Esan, E.B., Ogunwemimo, K.O., Denton, O.A. and Bolaji, D.T., (2015). Comparative studies on phytochemical and proximate composition of four morphological distinct segment of the conophor seedlings (Tetracarpidum conopphorum Hutch and Dalziel). Brazilian Journal of Biological Sciences, 3, 91-100.

Oyeyinka, S.A., Oyeyinka, A.T., Opaleke, D.O., Karim, O.R., Kolawole, F.L., Ogunlakin, G.O., and Olayiwola O.H., (2014). Cake production from wheat (Triticum aestivum) and cowpea (Vigna unguiculata) flours using 
date fruit as a sweetener. Annals of Food Science and Technology, 15(1), $20-28$.

Pasqualone, A., Bianco, A.M., and Paradiso, V.M. (2013). Production trials to improve the nutritional quality of biscuits and to enrich them with natural anthocyanin. CyTA-Journal of Food, 11(4), $301-308$.

Pereira, M.C., Steffens, R.S., Jablonski, A., Hertz, P.F., Rios, A.O., Vizzotto, M., and Flôres, S.H. (2013). Characterization, bioactive compounds and antioxidant potential of three Brazilian fruits. Journal of Food Complied Analysis, 29(1), 19-24.

Pokorný J. (2003). The impact of food processing in phytochemicals, In: I. Johnson, and G. Williamson (Eds.), Phytochemical Functional Foods, Woodhead Publishing Limited, Abington, Cambridge, England.

Romoke WA (2009). Nutritional value of walnut in Daily Trust, September 18, 2009, Nigeria. 